\title{
Effect of a Long Acting Glucagon Selective Somatostatin Analogue on Plasma Glucose, Insulin and Glucagon Levels in the Anaesthetized Rat during Arginine Infusion
}

\author{
E. Lien and D. Sarantakis \\ Research Division, Wyeth Laboratories, Philadelphia, Pennsylvania, USA
}

\begin{abstract}
Summary. The effects of somatostatin and a long acting, glucagon selective somatostatin analog (desAla ${ }^{1} \mathrm{Gly}^{2}\left[\mathrm{His}^{4,5}-\mathrm{D}-\operatorname{Trp}^{8}\right]$-somatostatin), were studied during arginine tolerance tests in normal anaesthetized rats. Arginine infusion in control animals resulted in a rapid increase in plasma insulin and glucagon, and an increase of $15 \pm 5 \mathrm{mg} / \mathrm{dl}$ in plasma glucose. Somatostatin infusion $(1 \mathrm{mg} / \mathrm{kg} / \mathrm{h})$ resulted in suppression of basal insulin secretion and a decrease in arginine-induced insulin and glucagon release. Glucose levels increased rapidly during the combined arginine-somatostatin infusion reaching a peak of $72 \pm 10 \mathrm{mg} / \mathrm{dl}$ above basal levels. Similar results were obtained when somatostatin was injected $\mathrm{SC}(1 \mathrm{mg} / \mathrm{kg})$ at times $0,15,30$, and 45 minutes (arginine infused from 30-60 minutes). A single injection $(1 \mathrm{mg} / \mathrm{kg})$ of the long-acting somatostatin analogue resulted in significant inhibition of basal insulin and glucagon release; during arginine infusion glucagon levels rose only slightly, the insulin response was, however, nearly normal, and only a small arginine-induced increase in glucose levels was observed. Carbohydrate absorption was not influenced by either somatostatin or the analogue.
\end{abstract}

Key words: Somatostatin, somatostatin analogues, insulin, glucagon, arginine, rat.

Somatostatin has been shown to inhibit the release of insulin [1] and glucagon [2], as well as numerous other hormones [3]. Although a transient decrease in glucose levels has been observed when somatostatin was infused into normal humans $[4,5]$ or maturityonset diabetics [6], glucose levels slowly increased after the nadir was reached. Intravenous glucose tolerance and arginine-infusion tests during somatostatin infusion also resulted in abnormal glucose profiles [7-9]. Elevated glucose levels in the above cases most likely resulted from prolonged suppression of insulin release. Somatostatin analogues which selectively inhibit glucagon release, such as [D-Cys $\left.{ }^{14}\right]$ somatostatin [10], do not possess the hyperglycaemic action of somatostatin itself. In a previous study a concomitant infusion of somatostatin and arginine into normal rats resulted in marked hyperglycaemia while infusion of saline or [D-Cys $\left.{ }^{14}\right]$-somatostatin in addition to arginine resulted in only a mild rise in blood glucose levels [11].

A long acting somatostatin analogue, des- $\mathrm{Ala}^{1}$ Gly $^{2}\left[\mathrm{His}^{4},{ }^{5}\right.$-D-Trp $\left.{ }^{8}\right]$-somatostatin (Wy-41,747) has previously been found to be a more potent suppressor of glucagon release than of insulin release [12]. The present study investigates the interaction of arginine with this peptide and with somatostatin in terms of pancreatic hormone release and glucose homeostasis. Rats received $\mathrm{Wy}-41,747$ as a single SC injection $(1 \mathrm{mg} / \mathrm{kg})$, while somatostatin, because of its short duration of action, was given either: (1) by the same route but in a divided dose (4 injections of $1 \mathrm{mg} / \mathrm{kg}$ spaced 15 minutes apart) or (2) at the same total dose as $\mathrm{Wy}-41,747(1 \mathrm{mg} / \mathrm{kg})$ but administered IV. Since fed rats were employed, changes in glucose absorption due to somatostatin and $\mathrm{Wy}-41,747$ were also studied.

\section{Materials and Methods}

Male Charles River CD rats weighing 300-350 g were anaesthetized with $50 \mathrm{mg} / \mathrm{kg}$ pentobarbital (IP) and anaesthesia maintained by hourly injections of pentobarbital, $10 \mathrm{mg} / \mathrm{kg}$. The jugular vein was cannulated for infusions and rats were treated with one of the following protocols: 1) somatostatin infusion ( $1 \mathrm{mg} / \mathrm{kg} / \mathrm{h}$ ) 
Table 1. Basal levels of plasma glucose, insulin, and glucagon ${ }^{a}$

\begin{tabular}{llcc}
\hline & $\begin{array}{l}\text { Glucose, } \\
\mathrm{mg} / \mathrm{dl}\end{array}$ & $\begin{array}{l}\text { Insulin, } \\
\mu \mathrm{U} / \mathrm{ml}\end{array}$ & $\begin{array}{l}\text { Glucagon, } \\
\mathrm{pg} / \mathrm{ml}\end{array}$ \\
\hline $\begin{array}{l}\text { Control }(\mathrm{n}=12) \\
\text { Somatostatin, }\end{array}$ & $81 \pm 4$ & $39 \pm 4$ & $118 \pm 11$ \\
$\begin{array}{l}\text { IV }(\mathrm{n}=9) \\
\text { Somatostatin, }\end{array}$ & $80 \pm 3$ & $48 \pm 5$ & $147 \pm 22$ \\
$\begin{array}{l}\text { SC ( }=6) \\
\text { Wy-41, 747, }\end{array}$ & $84 \pm 2$ & $33 \pm 7$ & $160 \pm 15$ \\
SC $(\mathrm{n}=12)$ & $87 \pm 6$ & $43 \pm 4$ & $150 \pm 18$ \\
\hline
\end{tabular}

a No significant differences were found between treatment groups. Significance assessed by analysis of variance

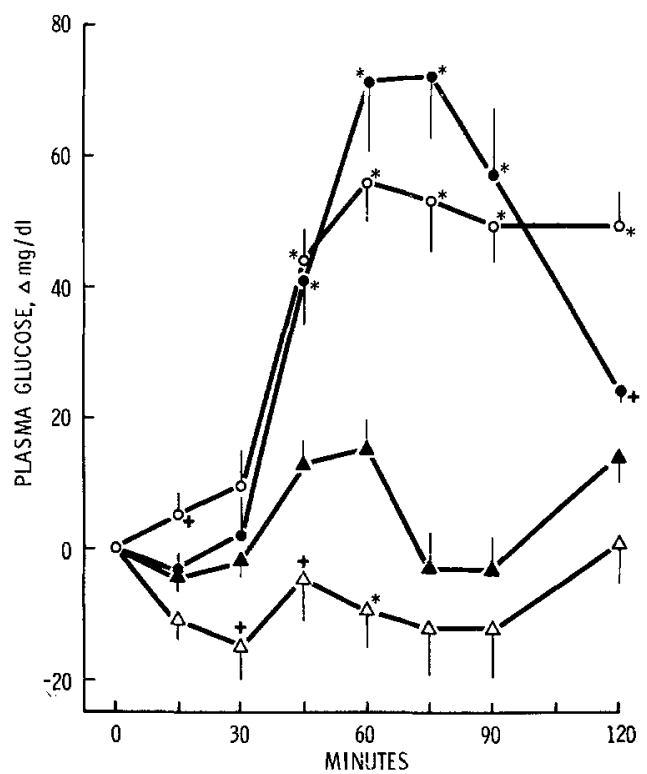

Fig. 1. Effect of somatostatin and $W y-41,747$ on plasma glucose during an arginine infusion $(100 \mathrm{mg} / \mathrm{kg} / \mathrm{h}$ from $30-60 \mathrm{~min})$. Somatostatin infusion from 0-60 minutes $(1 \mathrm{mg} / \mathrm{kg} / \mathrm{h}, \mathrm{n}=9)$ : - - somatostatin injections at $0,15,30$, and $45 \mathrm{~min}(1 \mathrm{mg} / \mathrm{kg}$ for each injection, $n=6): \bigcirc-O ; W y-41,747$ injection at time zero $(1 \mathrm{mg} / \mathrm{kg}, \mathrm{n}=12): \triangle-\triangle$; saline $(0.154 \mathrm{~mol} / \mathrm{l})$ infusion from 0-30 $\mathrm{min}(3 \mathrm{ml} / \mathrm{h}, \mathrm{n}=12)$; $\mathbf{A}-\boldsymbol{\Lambda}$. Vertical bars represent SEM; * $p<0.01 ;+p<0.05$. P values refer to peptide treated animals when compared to controls by analysis of variance

from $0-60 \mathrm{~min}$ plus arginine $(100 \mathrm{mg} / \mathrm{kg} / \mathrm{h}, \mathrm{pH}$ 7.2) from $30-60 \mathrm{~min} ; 2)$ a single $\mathrm{SC}$ injection of Wy-41,747 $(1 \mathrm{mg} / \mathrm{kg})$ at zero time plus an identical arginine infusion from $30-60 \mathrm{~min} ; 3$ ) $\mathrm{SC}$ somatostatin injections $(1 \mathrm{mg} / \mathrm{kg})$ given at $0,15,30$, and $45 \mathrm{~min}$ and an arginine infusion from $30-60 \mathrm{~min} ; 4$ ) saline infusion $(0.154 \mathrm{~mol} / \mathrm{l})$ from time $0-30 \mathrm{~min}$ followed by arginine alone from $30-60 \mathrm{~min}$. Blood samples were collected from the jugular vein and mixed with Trasylol-EDTA (600 units of Trasylol and $1.2 \mathrm{mg}$ EDTA per $0.5 \mathrm{ml}$ of blood).

Carbohydrate absorption was measured in 18 hour fasted, pentobarbital anaesthetized rats. A $20 \mathrm{~cm}$ segment of small intestine distal to the duodenal-jejunal junction was ligated (both proximally and distally) and $1.0 \mathrm{ml}$ of ${ }^{14} \mathrm{C}-3-0$-methyl glucose (New England Nuclear) placed in the loop. The concentration of 3-0methyl glucose in the loop was either $20 \mu \mathrm{mol} / 1$ or $30 \mathrm{mmol} / 1$ (specific activity of $53 \mathrm{mCi} / \mathrm{mmol}$ or $1.7 \mathrm{mCi} / \mathrm{mmol}$ ). Appearance of ${ }^{14} \mathrm{C}$ (total $\mathrm{cpm} / \mathrm{ml}$ ) was measured in plasma during infusion of somatostatin $(1 \mathrm{mg} / \mathrm{kg} / \mathrm{h})$ or saline $(3 \mathrm{ml} / \mathrm{h})$, following a $1 \mathrm{mg} / \mathrm{kg}$ injection of $\mathrm{Wy}-41,747$, or when labelled 3-0-methyl glucose and $5 \mathrm{mmol} / \mathrm{l}$ of phloridzin were placed in the loop together; infusions were started immediately after 3-0-methyl glucose was placed in the intestinal loop. Radioactivity was determined by obtaining plasma as above and counting $100 \mu \mathrm{l}$ in $10 \mathrm{ml}$ Biofluor (New England Nuclear).

Hormone levels were measured by radioimmunoassay: insulin by the method of Hales and Randle [13], and glucagon by the method of Faloona and Unger [14] using Unger 30K glucagon antiserum. Glucose was determined by the glucose-oxidase method. Statistical significance was evaluated using analysis of variance. Results are presented as mean $\pm \mathrm{SEM}$.

\section{Results}

Mean basal glucose, insulin and glucagon levels are listed in Table 1 for the different experimental groups; no significant differences were found. Plasma glucose levels did not change substantially in rats receiving either a saline or a somatostatin infusion during the basal period of the protocol (Fig. 1). A small $(5 \pm 2 \mathrm{mg} / \mathrm{dl})$ increase in the plasma glucose of rats receiving $1 \mathrm{mg} / \mathrm{kg} \mathrm{SC}$ injections of somatostatin was noted at 15 minutes (significantly higher than controls, $\mathrm{p}<0.05$ ). Plasma glucose levels in animals treated with a single $1 \mathrm{mg} / \mathrm{kg} \mathrm{SC}$ dose of $\mathrm{Wy}-41,747$ decreased progressively, reaching a nadir at 30 minutes (a decrease of $15 \pm 5 \mathrm{mg} / \mathrm{dl}, \mathrm{p}<0.05 \mathrm{com}$ pared to saline treated animals); additionally, the area under the glucose curve of $\mathrm{Wy}-41,747$-treated animals was significantly less than controls during the basal period (Table 2).

Plasma glucose levels increased $15 \pm 5 \mathrm{mg} / \mathrm{dl}$ during the infusion of arginine alone and returned to pre-infusion levels immediately after the infusion (Fig. 1). In contrast, infusion or injection of somatostatin resulted in hyperglycaemia during and after the arginine infusion. In animals receiving somatostatin by infusion the maximal increment in plasma glucose, $72 \pm 10 \mathrm{mg} / \mathrm{dl}$, occurred 15 minutes post-infusion. The combination of somatostatin SC injections and an arginine infusion resulted in a peak glucose rise of $56 \pm 7 \mathrm{mg} / \mathrm{dl} 30$ minutes after the start of the arginine infusion; under these conditions glucose levels remained elevated for the duration of the experiment. During the arginine infusion glucose levels increased transiently in animals treated with Wy-41,747, but remained significantly lower than controls. The areas under the glucose curves during and after the arginine infusion were significantly higher than controls in both somatostatin-treated groups ( $p<0.01$ in all cases) and significantly lower than controls in Wy-41,747-treated animals (Table 2). 
Table 2. Incremental area under glucose, glucagon and insulin curves ${ }^{a}$ before, during and after arginine infusions in animals treated with somatostatin or $\mathrm{Wy}-41,747$

\begin{tabular}{|c|c|c|c|c|}
\hline Time & Control & Somatostatin, $\Gamma^{b}$ & Somatostatin, $\mathrm{SC}^{\mathrm{b}}$ & $\mathrm{Wy}-41,747^{\mathrm{b}}$ \\
\hline \multicolumn{5}{|c|}{ Glucose (mg.min/ml) } \\
\hline $0-30$ & $-0.2 \pm 0.4$ & $0.4 \pm 0.8$ & $0.1 \pm 0.1$ & $-3.1 \pm 0.9^{c}$ \\
\hline $30-60$ & $3.8 \pm 0.7$ & $12.2 \pm 2.1^{d}$ & $12.8 \pm 1.9^{d}$ & $-2.1 \pm 1.9^{d}$ \\
\hline $60-120$ & $3.9 \pm 1.9$ & $29.7 \pm 5.0^{d}$ & $30.7 \pm 2.5^{d}$ & $-7.0 \pm 4.1^{c}$ \\
\hline \multicolumn{5}{|c|}{ Glucagon $(\mathrm{pg} \cdot \mathrm{min} / \mathrm{ml})$} \\
\hline $0-30$ & $-65 \pm 268$ & $-375 \pm 213$ & $209 \pm 219$ & $1115 \pm 246^{d}$ \\
\hline $30-60$ & $1982 \pm 562$ & $-241 \pm 325^{d}$ & $570 \pm 472$ & $-681 \pm 391^{d}$ \\
\hline $60-120$ & $776 \pm 530$ & $567 \pm 592$ & $80 \pm 595$ & $-1590 \pm 944$ \\
\hline \multicolumn{5}{|c|}{ Insulin $(\mu \mathrm{U} \cdot \mathrm{min} / \mathrm{ml})$} \\
\hline $0-30$ & $66 \pm 177$ & $-633 \pm 104^{d}$ & $-236 \pm 124$ & $-882 \pm 119^{d}$ \\
\hline $30-60$ & $3439 \pm 497$ & $-200 \pm 218^{d}$ & $235 \pm 185^{d}$ & $2124 \pm 162^{c}$ \\
\hline $60-120$ & $1403 \pm 281$ & $2295 \pm 1058$ & $79 \pm 362^{d}$ & $1149 \pm 403$ \\
\hline
\end{tabular}

a Treatment groups are described in Materials and Methods. Somatostatin IV was given from 0 to 60 minutes, Somatostatin SC was given at $0,15,30$ and $45 \mathrm{~min}$., Wy-41,747 was given at time 0 , arginine was given from 30-60 min. Number of animals per group: control: 12 ; somatostatin, IV: 9; somatostatin, SC: 6 ; Wy-41, 747: 12

${ }^{b}$ Statistical variation from control determined by analysis of variance; ${ }^{c} p<0.05 ;{ }^{d} p<0.01$

Basal plasma glucagon levels were not significantly altered by somatostatin infusion or injection while injection of $\mathrm{Wy}-41,747$ resulted in a rapid decrease in glucagon levels, reaching a nadir in $15 \mathrm{~min}$ (significantly lower than the other three groups) (Fig. 2). The incremental area under the glucagon curve was significantly less in the Wy- 41 , 747 treated group than in the other three groups (Table 2). Plasma glucagon levels increased in control animals during the arginine infusion (a peak increase of $76 \pm 17 \mathrm{pg} / \mathrm{ml}$ was reached 15 minutes after initiation of the arginine infusion) and returned to basal levels following the infusion. Although glucagon levels tended to increase during the arginine infusion in the three peptide-treated groups, the increase was smaller than in controls, and significant differences were noted when controls were compared to each of the other groups (Fig. 2). Glucagon levels in both somatostatin-treated groups rose to values significantly higher than control at the end of the experiment ( 60 minutes post infusion), while glucagon levels in the Wy-41,747-treated group decreased immediately following the arginine infusion. The incremental area under the glucagon curve was significantly lower in the somatostatin infusion and Wy-41,747-treated groups than control during the arginine infusion (Table 2).

A highly significant decrease in basal plasma insulin levels was noted during somatostatin infusion or following injection of Wy-41,747 (Fig. 3); maximal insulin reductions of $65 \%$ during somatostatin infusion and of $79 \%$ in the $\mathrm{Wy}-41,747$-treated group occurred. Basal insulin levels in animals receiving SC injections of somatostatin were not significantly altered. During arginine infusion in the control group

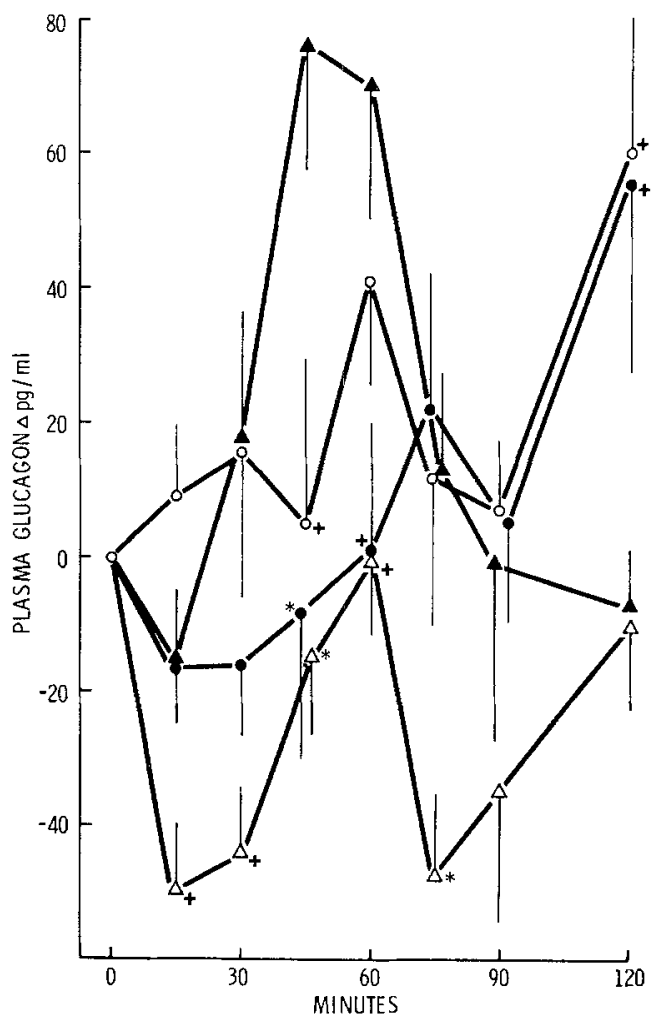

Fig. 2. Effect of somatostatin and $\mathrm{Wy}-41,747$ on plasma glucagon during an arginine infusion (100 mg $/ \mathrm{kg} / \mathrm{h}$ from $30-60$ minutes). Somatostatin infusion from $0-60$ minutes $(1 \mathrm{mg} / \mathrm{kg} / \mathrm{h}, \mathrm{n}=9)$ : - - somatostatin injections at $0,15,30$, and $45 \mathrm{~min}(1 \mathrm{mg} / \mathrm{kg}$ for each injection, $\mathrm{n}=6): \mathrm{O}-\mathrm{Wy}-41,747$ injection at time zero $(1 \mathrm{mg} / \mathrm{kg}, \mathrm{n}=12): \triangle-\triangle$; saline infusion from $0-30$ minutes $(3 \mathrm{ml} / \mathrm{h}, \mathrm{n}=12): \mathbf{\Delta}-\mathbf{A}$. Vertical bars represent SEM; $* \mathrm{p}<0.01$; $+p<0.05$. P values refer to peptide treated animals when compared to controls by analysis of variance 


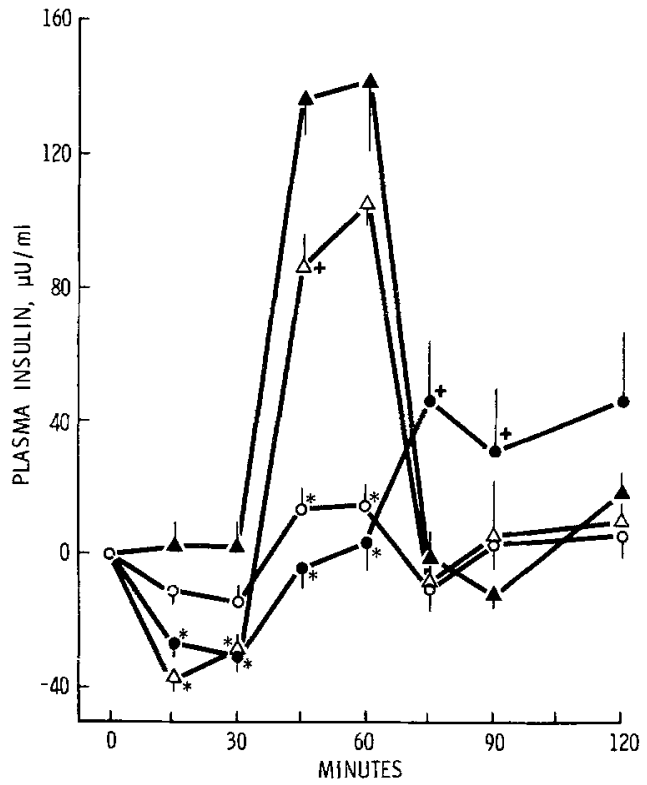

Fig. 3. Effect of somatostatin and $W y-41,747$ on plasma insulin during an arginine infusion $(100 \mathrm{mg} / \mathrm{kg} / \mathrm{h}$ from $30-60 \mathrm{~min})$. Somatostatin infusion from $0-60 \mathrm{~min}(1 \mathrm{mg} / \mathrm{kg} / \mathrm{h}, \mathrm{n}=9)$; somatostatin injections at $0,15,30$, and $45 \mathrm{~min}(1 \mathrm{mg} / \mathrm{kg}$ for each injection, $\mathrm{n}=6): \mathrm{O}-\mathrm{O}$;y-41,747 injection at time zero $(1 \mathrm{mg} /$ $\mathrm{kg}, \mathrm{n}=12): \triangle-\triangle$; saline infusion from $0-30 \mathrm{~min}(3 \mathrm{ml} / \mathrm{h}$, $\mathrm{n}=12): \boldsymbol{\Lambda}-\boldsymbol{\Delta}$. Vertical bars represent SEM; ${ }^{*} \mathrm{p}<0.01 ;+\mathrm{p}<$ 0.05 . $P$ values refer to peptide treated animals when compared to controls by analysis of variance

insulin levels followed a pattern similar to that for glucagon: a rapid increase at the initiation of the infusion and an rapid decrease upon termination of the infusion (Fig. 3). The insulin response to arginine in both somatostatin treated groups was minimal; a rebound occurred at the end of the arginine infusion in the group receiving concomitant infusion of somatostatin, while no rebound was observed in animals receiving SC somatostatin. During and after the arginine infusion the response of animals treated with Wy-41,747 was similar to controls, although peak values were lower in peptide treated animals. The incremental area under the insulin curve was significantly less in somatostatin-and $\mathrm{Wy}-41,747$-treated groups than controls during arginine infusion; additionally, the area under the insulin curve during arginine infusion was significantly larger for the Wy41,747 group than for either of the somatostatin groups $(\mathrm{p}<0.01)$.

To investigate the possibility of altered carbohydrate absorption due to somatostatin or $\mathrm{Wy}-41,747$, ${ }^{14} \mathrm{C}-3-0$-methyl glucose was placed in a ligated loop of rat intestine. The appearance of ${ }^{14} \mathrm{C}$ in plasma was similar in animals infused with saline or somatostatin $(1 \mathrm{mg} / \mathrm{kg} / \mathrm{h})$ or injected SC with $1 \mathrm{mg} / \mathrm{kg} \mathrm{Wy}-41,747$ when $1 \mathrm{ml}$ of $20 \mu \mathrm{mol} / \mathrm{l}{ }^{14} \mathrm{C}-3-0$-methyl glucose was

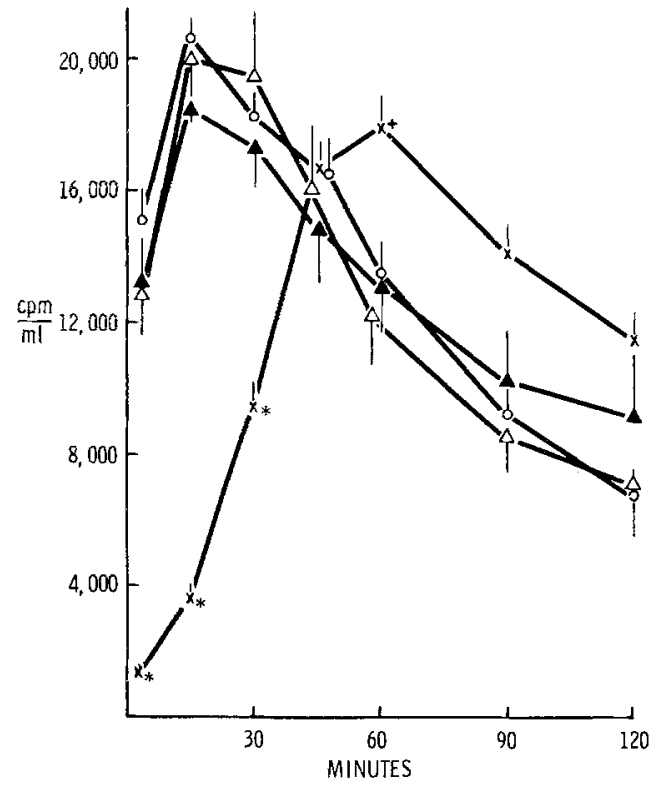

Fig. 4. Absorption of ${ }^{14} \mathrm{C}-3-\mathrm{O}$-methyl glucose $(1 \mu \mathrm{Ci}, 20 \mu \mathrm{mol} / \mathrm{l})$ from a ligated intestinal loop. ${ }^{14} \mathrm{C}$ determined in plasma of animals receiving: a somatostatin infusion from $0-120 \mathrm{~min}(1 \mathrm{mg} / \mathrm{kg} / \mathrm{h}$, $\mathrm{n}=8): \bigcirc-O$; a saline infusion from $0-120 \mathrm{~min}(3 \mathrm{ml} / \mathrm{h}, \mathrm{n}=8)$ : $\Delta-\boldsymbol{A}$; an injection of $W \mathrm{y}-41,747$ at time zero $(1 \mathrm{mg} / \mathrm{kg}, \mathrm{n}=8)$ : $\triangle-\triangle$; phloridzin incubated in the intestinal loop $(5 \mathrm{mmol} / 1$, $\mathrm{n}=8$ ): $\times-\times$. Vertical bar bars represent SEM; $* \mathrm{p}<0.01 ;+\mathrm{p}$ $<0.05$. $P$ values refer to experimental group when compared to control animals by analysis of variance

placed in the intestinal loop (Fig. 4). Similar results were obtained with $30 \mathrm{mmol} / 1{ }^{14} \mathrm{C}-3-0$-methyl glucose (data not shown). When $5 \mathrm{mmol} / \mathrm{l}$ phloridzin, an inhibitor of active glucose transport, was placed in the loop in addition to the sugar, a strong initial inhibition was observed in the plasma appearance of ${ }^{14} \mathrm{C}$ (Fig. 4).

\section{Discussion}

Somatostatin was administered by two different routes in the present study. The group infused with somatostatin received the same total dose of peptide as the Wy-41,747 group $(1 \mathrm{mg} / \mathrm{kg})$, while the second somatostatin group received somatostatin via the same route as the $\mathrm{Wy}-41,747$ group (subcutaneously), but at a higher dose. These alterations in protocol were necessary due to the short biological half life of somatostatin $(15,16)$. Basal glucagon levels were not altered by somatostatin infusion or injections at the doses employed in this study, while insulin levels were significantly lowered by the somatostatin infusion. In contrast, a single SC dose of the somatostatin analogue $\mathrm{Wy}-41,747$ resulted in a significant decrease of both plasma glucagon and insu- 
lin, followed by a reduction of plasma glucose. Arginine infusion produced opposite plasma glucose responses in rats treated with somatostatin or $\mathrm{Wy}-41$, 747. Although the somatostatin-treated groups displayed a diabetogenic response, glucose values in the Wy-41,747 group were consistently below control values. During the arginine and somatostatin infusion increasing levels of glucagon, capable of stimulating hepatic glycogenolysis [17], coupled with lowered glucose clearance rates due to suppressed insulin release (compared to the control group) presumably resulted in hyperglycaemia. Recent studies in humans [9] have demonstrated that arginine stimulates hepatic glycogenolysis while not substantially altering hepatic gluconeogenesis, since splanchnic glucose output increased dramatically in postabsorptive normal subjects but not in 60 hour fasted subjects. In agreement with the results of the present study, concomitant arginine and somatostatin infusion produced hyperglycaemia in normal humans [8, 9] and maturity-onset diabetics [8]. The hyperglycaemia in normal humans resulted from a normal arginine-induced increase in splanchnic glucose output and a decreased glucose clearance rate due to lowered insulin levels [9]. In contrast, administration of $\mathrm{Wy}-41,747$ resulted in a more complete suppression of glucagon release while insulin release was similar to controls during the arginine infusion. Glucose levels during the arginine infusion in $\mathrm{Wy}-$ 41,747-treated animals increased only slightly, thus demonstrating the relative importance of pancreatic glucagon secretion in stimulating hepatic glucose release.

The animals in the above experiments were not fasted since high levels of liver glycogen were desirable in order to obtain a maximal glucose response to arginine. If $\mathrm{Wy}-41,747$ or somatostatin altered glucose absorption, then factors other than hormonal ones might be partly responsible for altered glucose levels. Glucose absorption was studied using a glucose analogue, 3-0-methyl glucose, which is absorbed via mechanisms similar to glucose but is not further metabolized [18]. Two concentrations of the sugar were employed: (1) $20 \mu \mathrm{mol} / 1$, a concentration below normal blood glucose levels with absorption into the peripheral circulation being due to active transport, and (2) $30 \mathrm{mmol} / \mathrm{l}$, a concentration above the normal blood glucose concentration with peripheral appearance of the sugar being due to a combination of active and passive transport. In contrast to studies in humans, the present results suggest that carbohydrate absorption is not influenced by somatostatin in the rat. Phloridzin, a known inhibitor of active glucose transport [19], strongly inhibited the appearance of radioactivity in the peripheral circulation. This experiment served as a positive control, demonstrating that active transport could be inhibited in this system.

Abnormal $\alpha$-cell function has been noted under a variety of conditions in both maturity-onset and juvenile diabetics. Fasting hyperglucagonaemia relative to plasma glucose levels has been reported in both types of diabetics [20]. Aydin et al. [21] found elevated glucagon levels during an oral glucose tolerance test in the absence of exogenous insulin in both types of diabetics and normalization of insulin levels by infusion of exogenous insulin for short periods still resulted in an abnormal glucagon response. Abnormal glucagon responses have also been reported during arginine infusion studies in both maturity-onset and juvenile type diabetics $[20,22]$. A somatostatin analogue with relative glucagon specificity and a prolonged duration of action could be of value in treating maturity-onset diabetics since abnormally high glucagon levels would be reduced without severely altering $\beta$-cell function. This type of analogue would also have an advantage over somatostatin analogues with both insulin and glucagon activities in treating some cases of juvenile type diabetes. Recent studies have indicated that many well controlled juvenile diabetics have residual $\beta$-cell function as measured by the presence of circulating $C$ peptide [23, 24], while brittle diabetics have undetectable $C$ peptide levels [25]. A somatostatin analogue selectively inhibiting glucagon release would not alter residual $\beta$-cell function, while an analogue without this specificity would suppress endogenous insulin release.

Acknowledgement. We would like to acknowledge the skilful technical assistance of Gerald Deitch and Ann Morrison.

\section{Reference}

1. Alberti, K. G. M. M., Christensen, N. J., Christensen, S. E., Hansen, Aa. P., Iversen, J., Lundbaek, K., Seyer-Hansen, K., Ørskov, H.: Inhibition of insulin secretion by somatostatin. Lancet 1973 II, 1299-1301

2. Gerich, J. E., Lorenzi, M., Schneider, J., Kwan, C. W., Karam, J. H., Guillemin, R., Forsham, P. H.: Inhibition of pancreatic glucagon responses to arginine by somatostatin in normal man and insulin-dependent diabetics. Diabetes 23, 876-880 (1974)

3. Guillemin, R., Gerich, J. E.: Somatostatin: physiological and clinical significance. Annu. Rev. Med. 27, 379-388 (1976)

4. Lins, P. E., Efendic, S.: Hyperglycemia induced by somatostatin in normal subjects. Horm. Metab. Res. 8, 497-498 (1976)

5. Sherwin, R. S., Hendler, R., DeFronzo, R., Wahren, J., Felig, P.: Glucose homeostasis during prolonged suppression of glucagon and insulin secretion by somatostatin. Proc. Natl. Acad. Sci. USA 74, 348-352 (1977)

6. Tamborlane, W. V., Sherwin, R. S., Hendler, R., Felig, P.: Metabolic effects of somatostatin in maturity-onset diabetics. N. Engl. J. Med. 297, 181-183 (1977) 
7. Leblanc, H., Anderson, J. R., Sigel, M. B., and Yen, S. S. C.: Inhibitory action of somatostatin on pancreatic $\alpha$ and $\beta$ cell function. J. Clin. Endocrinol. Metab. 40, 568-572 (1975)

8. Waldhäusl, W., Bratusch-Marrain, P., Dudczak, R., Deutsch, E.: The diabetogenic action of somatostatin in healthy subjects and in maturity onset diabetics. J. Clin. Endocrinol. Metab. 44, 876-883 (1977)

9. Bratusch-Marrain, P., Björkman, O., Hagenfeldt, L., Waldhäusl, W., Wahren J.: Influence of arginine on splanchnic glucose metabolism in man. Diabetes 28, 126-131 (1979)

10. Brown, M., Rivier, J., Vale, W.: Somatostatin: analogs with selected biological activities. Science 196, 1467-1469 (1977)

11. Lien, E. L.: Effect of somatostatin and a glucagon-specific analog on glucose homeostasis during arginine infusion. Metabolism 27, 1095-1100 (1978)

12. Sarantakis, D., Teichman, J., Fenichel, R., Lien, E.: [des-Ala ${ }^{1}$, $\left.\mathrm{Gly}^{2}\right]-\mathrm{His}^{4},{ }^{5} \mathrm{D}$-Trp ${ }^{8}$-somatostatin. A glucagon-specific and longacting somatostatin analog. FEBS Lett. 92, 153-155 (1978)

13. Hales, C. N., Randle, P. J.: Immunoassay of insulin with insulin antibody recipitate. Biochem. J. 88, 137-148 (1963)

14. Faloona, G. R., Unger, R. H.: Glucagon. In: Methods of hormone radioimmunoassay. Jaffe, B. M., Behrman, H. R. (eds.), pp 317-330. New York: Academic Press 1974

15. Brazeau, P., Rivier, J., Vale, W., Guillemin, R.: Inhibition of growth hormone secretion in the rat by synthetic somatostatin. Endocrinology 94, 184-187 (1974)

16. Leblanc, H., Rigg, L., Yen, S.: The response of pancreatic and pituitary hormones to pulse and constant infusion of somatostatin. J. Clin. Endocrinol. Metab. 41, 1105-1109 (1975)

17. Salter, J.M., Eyrin, C., Laidlaw, J.C., Gornall, A. G.: Metabolic effects of glucagon in human subjects. Metabolism 9, 753-768 (1960)

18. Lichtenstein, B., Winne, D.: The influence of blood flow on the absorption of 3-0-methyl glucose from the jejunum of the rat. Naunyn Schmiedebergs Arch. Pharmacol. 279, 153-172 (1973)
19. Alvarado, F., Crane, R. K.: Phlorizin as a competitive inhibitor of the active transport of sugars by hamster small intestine, in vitro. Biochim. Biophys. Acta 56, 170-172 (1962)

20. Unger, R.H., Aguilar-Parada, E., Muller, W. A., Eisentraut, A. M.: Studies of pancreatic alpha cell function in normal and diabetic subjects. J. Clin. Invest. 49, 837-848 (1970)

21. Aydin, I., Raskin, P., Unger, R. H.: The effect of short-term intravenous insulin administration on the glucagon response to a carbohydrate meal in adult onset and juvenile type diabetes. Diabetologia 13, 629-636 (1977)

22. Ohneda, A., Ishii, S., Horigome, K., Yamagata, S.: Glucagon response to arginine after treatment of diabetes mellitus. Diabetes 24, 811-819 (1975)

23. Ludvigsson, L., Heding, L. G.: C-peptide in children with juvenile diabetes. A preliminary report. Diabetologia 12, 627-630 (1976)

24. Grajwer, L. A., Pildes, R. S., Horwitz, D. L., Rubenstein, A. H.: Control of juvenile diabetes mellitus and its relationship to endogenous insulin secretion as measured by C-peptide immunoreactivity. J. Pediatr. 90, 42-48 (1977)

25. Shima, K., Tanaka, R., Morishita, S., Tarui, S., Kamahara, Y., Nishikawa, M.: Studies on the etiology of "brittle diabetes". Relationship between diabetic instability and insulinogenic reserve. Diabetes 26, 717-725 (1977)

Received: May 15, 1978,

and in revised form: April 21, 1979

Dr. Eric Lien

Wyeth Laboratories

Research Division

P. O. Box 8299

Philadelphia, PA 19101

USA 